\title{
AC 2008-1302: TRANSFER STUDENTS: TAILORING A FRESHMAN PROGRAM TO THEIR NEEDS
}

\section{Jean Kampe, Virginia Polytechnic Institute and State University}

J. C. MALZAHN KAMPE is an Associate Professor in the Department of Engineering Education at Virginia Polytechnic Institute and State University. She received a Ph.D. in Metallurgical Engineering from Michigan Technological University, an M.Ch.E. in Chemical Engineering from the University of Delaware, and a B.S. in Chemical Engineering from Michigan Technological University.

\section{Whitney Edmister, Virginia Polytechnic Institute and State University}

WHITNEY A. EDMISTER is the Assistant Director of the Center for the Enhancement of Engineering Diversity at Virginia Polytechnic Institute and State University. She received her M.S. in Counselor Education, Student Affairs Administration from Radford University, and M.S. in Career and Technical Education and B.S. in Human Nutrition, Foods and Exercise both from Virginia Polytechnic Institute and State University.

\section{Christi Boone, Virginia Polytechnic Institute and State University}

C. L. BOONE is the Coordinator of Academic Support Services for the College Of Engineering at Virginia Polytechnic Institute and State University. She received her M.A. \& B.A. degrees in English from Radford University.

\section{Bevlee Watford, Virginia Polytechnic Institute and State University}

DR. BEVLEE A. WATFORD, P.E. is the founding Director of the Center for the Enhancement of Engineering Diversity, established in 1992. Watford received the ASEE 2003 Minorities in Engineering award due to her efforts to increase the recruitment, retention, and graduation rates of under-represented students in engineering. She has recently returned to Virginia Tech as Associate Dean for Academic Affairs and Professor of Engineering Education following a 2 year rotation working for the National Science Foundation as a program manager in the Division of Undergraduate Education. 


\title{
Transfer Students: Tailoring a Freshman Program to their Needs
}

\begin{abstract}
At a large public university, the class entering the College of Engineering comprises freshmen and transfer students, and the latter are predicted to increase in number in the coming years. When transfer students move to a university engineering program, they often encounter a "Freshman Program" that impedes full articulation in transfer to the university. Freshman programs that are designed to inform traditional freshmen of the available engineering majors, and to prepare them for academic success within those majors, usually have a full year of required "Introduction to Engineering" type courses. These courses are usually prerequisites either for entry to the degree-granting programs or for subsequent required courses in any engineering path. Transfer students who cannot cover these introductory freshman engineering courses with transferred credits are often essentially relegated back to freshman status and to taking the freshman program courses - and this is not a good situation. At Virginia Tech, about 150 transfer students on average enter the College of Engineering $(\mathrm{CoE})$ each fall, and anywhere from about one quarter to one third of them require the freshman program courses. In past years, we sprinkled these transfer students among the traditional freshmen in the many sections ( 40) of the first engineering course. In fall 2006, however, at the prompting of the CoE Academic Affairs office, a new course was offered to replace both semesters of the freshman program for transfer students. This new course, along with a peer-mentoring program for transfer students that had been initiated the prior year, seemed to offer a much needed support system for the transfer students. The synergistic impact of the fall 2006 course and the concurrent mentoring program led to slating the course for transfers as a summer 2007 offering with the mentoring effort integrated into the course. This paper provides details on course design and administration, and on the integration of the peer-mentoring program. Student evaluations of the course and the mentoring are provided, as are insights from the summer mentors. This program, tailored for transfer students, is also suitable for true freshmen who enter with substantial advanced placement (AP) or dual enrollment credit.
\end{abstract}

\section{Introduction}

Today, many people are opting to begin their engineering education at community college and then transfer to a four-year institute. Escalation of college costs ${ }^{1-4}$ is the major motivation driving this trend, ${ }^{5}$ but community colleges offer more than just a less expensive trek through the first two years. They often provide a smaller, more intimate campus, and a greater flexibility in class scheduling, with more evening classes. They also offer an opportunity to pick up remedial math and science for those who decide to pursue engineering too late to prepare for that path in high school. ${ }^{6}$ With a transfer in mind, taking fundamental freshman- and sophomore-level courses at a community college can also mitigate a rocky academic start toward a four-year degree. For those recent high school graduates and those older students who are unsure of which major to pursue, less expensive part-time academic explorations at community college offer the ability to hold a full time job while deciding on future directions. Most engineering transfer students do hale from community colleges, and for non-elite receiving universities, the number of community college transfer students is on the rise and expected to increase steadily over the coming years. ${ }^{6,7}$ In fact, a recent report by both the National Academy 
of Engineering and the National Research Council has concluded that "...community college transfer may be the primary mechanism for increasing the number of students pursuing engineering degrees, particularly under-represented minority students." ${ }^{5}$ There are also students who transfer from one four-year institute to another, and these moves include both in-state and out-of-state transfers. Additionally, in the United States, several states have many small (e.g., satellite) campuses that compose, in part, a state network that offers engineering only at a few larger universities in the system. Such state systems are typically designed to smoothly accommodate articulation to the larger university in order to provide ready access to higher education across state territories. For these state systems, however, there are sometimes still glitches in the "equivalency" of courses. Nationally, as the numbers of transfer students rise, there is a growing awareness of issues associated with transfer student populations and a growing desire to facilitate transfers, ${ }^{5-9}$ even at elite institutions which are viewed by some as "closed" to transfer students. ${ }^{10}$ For those receiving institutions with a mandatory first-year engineering program, the existence of the freshman program can be a major impediment to articulation for engineering students. Such was the case at Virginia Tech, and it was time to address that specific transfer roadblock.

\section{Background}

At Virginia Tech, the freshman program has long been ingrained in the College of Engineering. It is now a four-credit two-course sequence with a common first course and a second course that is selected from two options, depending on intended major. The sequence courses must be successfully completed to continue engineering coursework and, along with other freshman requirement courses (Calculus, Chemistry, Physics, and English), to enter a degree-granting department in the college. There is a strong design thread that runs through the sequence, and a teamwork component in all three courses. The engineering disciplines and the degree programs within the college are introduced in the common first course, and the students select the second course of the sequence based on their intended major, with one track heading for electrical engineering, computer engineering, or computer science, and the alternate track heading for the other ten engineering degrees (e.g., mechanical, civil, chemical, ...). All freshmen and those transfer students who require the freshman program courses are admitted to the college as General Engineering (GE) students, and they are moved to their respective departments upon completion of the freshman requirements. Until fall 2006, the only exceptions to this one-year trek as a GE student were granted to those students who achieved a firstsemester fall grade point average of 3.4 or higher. Those people were invited to join their department of choice during the spring semester, but they still needed to complete all the freshman requirement courses. Most GE transfer students entering Virginia Tech's College of Engineering were thus looking at passage of a full year before they would be moved to the department of their intended major, with a longer time as a GE student if they encountered any academic difficulties in completing the freshman requirement courses that they lacked in transfer to Virginia Tech. The importance of changing this situation lies in the number of people affected, which is substantial for Virginia Tech. The number of new transfer students for the College of Engineering and the number of those needing the full freshman program are provided in Table I for fall 2005, 2006, and 2007. 
Table I. Number of transfer students entering Virginia Tech's College of Engineering (CoE) and the number of those students who needed the full freshman program course sequence.

\begin{tabular}{|l|c|c|}
\hline \multicolumn{1}{|c|}{ Entering Semester } & $\begin{array}{c}\text { Total number of new CoE } \\
\text { transfer students }\end{array}$ & $\begin{array}{c}\text { Number of new CoE transfer } \\
\text { students who needed both } \\
\text { freshman courses }\end{array}$ \\
\hline Fall 2005 & 154 & 48 \\
\hline Fall 2006 & 127 & 58 \\
\hline Fall 2007 & 168 & 38 \\
\hline
\end{tabular}

\section{Course for Transfers: Design and Administration}

In fall 2006, at the prompting of the College of Engineering's Academic Affairs office, a new course was offered for transfer students to replace both semesters of the freshman program courses. This new course, EngE2984, needed to cover the learning objectives of the common first semester course and those in both options of the second semester course, so that students completing EngE2984 could move into any department. The three freshman courses add to six credits, but after removing duplication of common material among the courses, the content remaining warranted a five-credit offering. The course was delivered through thirty 75 -minute lecture meetings and thirty workshops that were slated for two hours each. The fall 2006 semester spanned fifteen weeks for course delivery, so two lectures and two workshops were held each week. In moving to the summer 2007 offering, which spanned only six weeks, a lecture and then a workshop were held each weekday, with a two-hour break between them. A faculty member ran the lectures and workshops, but the workshops also had a teaching assistant: a graduate student in fall 2006 and an upper-class undergraduate in summer 2007. The breakdown of course content and delivery is presented in the Appendix (see Table A1, which is a compressed version of the summer course syllabus). The major content items for the course include graphics, design, problem solving, graphing, computer programming, handling digital data, project management, communication, and ethics. In each offering of EngE2984, a teambased major design project was assigned (see Workshops for Week 1 in Table A1). In assigning course grades, there are two benchmarks that must be met to earn a non-F grade. The first is a $60 \%$ or better individual grade on the team design project, and the second is earning $60 \%$ or more of the available points for computer programming efforts. Additionally, an EngE2984 course grade of $\mathrm{C}$ - or better is needed to meet the pre-requisite to continue to the next engineering course(s); this is true for all freshman program courses.

The main reason for offering this five-credit course is to move GE transfer students into their degree-granting departments as quickly as possible, so changing the course to a summer offering was an obvious outcome from the fall 2006 run. Summer II at Virginia Tech begins in early July and ends two weeks before the start of the fall semester. This timeline allows transfer students to complete prior spring requirements at their first institution and to meet the registration and enrollment deadlines of Virginia Tech. It also works well with high school graduation dates for advanced traditional freshmen. More importantly, taking EngE2984 in the six-week summer session can reduce the time to degree by up to one year for these students, allowing entry to their department at the start of their first regular academic semester. In terms 
of finances, the summer may be partly lost as an opportunity to make money for the subsequent school year, but there is the potential to replace payment of a year's worth of university tuition with earning a year's worth of professional salary.

In terms of course design, administration, and delivery, there were several points critical to making this course effective for transfer students. First, it was important to be aware that nearly every student enrolled in the course was a first-semester transfer student. While that may seem an obvious point, knowing that it substantially changes course dynamics is not obvious. What a professor usually experiences and/or expects when class body makeup is nearly all native students who began as freshmen at the institution, or even when the class body comprises only new freshmen, is quite different than the reality of teaching a room of new transfer students. Transfer students have some experience in higher education, but the amount and type of experience is not the same for all and they do not have the campus knowledge that native upperclass students do. They are generally older and more mature than new freshmen, with varied living arrangements and varied life styles, and they exist in varied places along life's path. In terms of the other courses they are taking, there is considerable difference from one student to the next due to varying academic levels and varying intended degree paths. Fundamental attitudes toward education and toward their own learning are often very different for transfer students, and so too are their motivations. So, in the presentation of course content, adjustments were made from the basic freshman plans to teach at a somewhat higher level but to maintain the freshman expectations when grading work. In the design of assignments, it was important to make strong links between class time activities/content and assigned homework. Also, making links between course efforts and real-life engineering was mandatory to keep students engaged. For the team-based design project, we needed to create a project that would be interesting and challenging, but also one that would ensure a team effort from these students who had so little beyond the class connecting them.

The project statement for the major team-based design effort is provided in Table A2 of the Appendix. In essence, the teams were assigned the task of reverse engineering an electromechanical device, creating working drawings of the device using Inventor, designing a device modification, and then implementing the modification only through additional Inventor work. A project report and presentation were also required. This project offered hands-on experience through the reverse engineering portion of the work. Our institution does not have the facilities to provide shop support for a freshman "design and construct" type project, so reverse engineering is a suitable alternative for a hands-on effort. Also, since understanding device operation is part of reverse engineering, the students are exposed to the design intricacies of a marketable device and how they impact device function. The selected device is a team choice to help instill project ownership, but that choice does require instructor approval for safety reasons and to ensure that each team is working on a different device. Then during project presentations, students learn about the operation of the many devices selected by the different teams. Instructor approval of the intended modification is also required, so that the difficulty of the Inventor effort for the project as a whole can be balanced among the teams by instructor intervention. Requiring instructor approval at two stages in the project also meant that student teams needed to meet with the instructor at least twice, and that was an important aspect for the course. Access to receiving university engineering professors should be early and often for transfer students to assuage any anticipated difficulties in making faculty connections ${ }^{8}$ and to facilitate student success. ${ }^{11}$ 
The major design project was team-based, and this required that the students enrolled in the course be distributed among teams. To start the process of making team assignments, students were asked to do a self assessment of skill sets that would be needed for the project and for computer programming, a major content area in EngE2984. The survey used is provided in Table II, and it also offered students the opportunity to select or decline the chance to work with another specific student. Using the information students provided through the survey, teams were assembled to balance the self-rated talents listed in survey Item 2 among all the teams. We made an effort to place an expert (rating of 5) in each talent on each team when possible. For the resultant teams, ideally each member then offered expertise in a given skill set. Computer programming was included in the skill set survey, though it was not directly required in the project, because when team members work well together, their peer learning and peer assistance usually extends to other course work beyond the limits of the project. In building teams so that each member has an inherent value that is critical to a team's success, teamwork is achieved more easily. This is particularly true if the students are aware of that manner of team construction and how to use it to their advantage. It is important to clarify that an expert's job is not to take on the full burden of that portion of the assignment, but rather to be a consultant. For example, in this design project, students were working with devices actually manufactured for sale, and the designs of external parts such as casings thus had much more complex curvature than student design/construct projects would normally include. This made for some difficult Inventor work, on top of a heavy Inventor load provided by the number of parts in each device. So, making it clear that the team's CAD expert was to serve as an Inventor consultant and was NOT to do all the Inventor work alone, helped the students understand teamwork. In fact, due to project time limitations and the amount and difficulty of the Inventor work, the students did see that the Inventor work needed to be distributed among all team members.

Table II. Team information survey for the design project and the course.

02 July 2007

EngE2984 Name:

(Last, First)

1. Major or intended major:

2. Rate your ability/experience/confidence in the following categories on a scale of $1-5$ with 5 being most confident, 1 being least

_ Carpentry / metalwork / minor auto repair / mechanical tinkering

_ CAD or Drafting

_ Computer Programming

_ Writing

_ Organization

4. Name of anyone you do NOT want on your team:

5. Name of one person you would like on your team: 
Another project aspect that was important for the transfer students was allowing class time for project teamwork. This was accomplished in two ways. First, workshops were slated for two-hour slots, but the time actually required for planned activities was usually 30 to 40 minutes. This left a substantial balance of workshop time that teams could, and did, use for project efforts. There were also one or two instances of giving the lecture time to students for project work. For transfer students, allowing class time for team-based efforts was critical to the success of teamwork. Many of the students had life situations that did not allow for easy evening gatherings for team meetings. Some were commuters. Some had children. Some worked. Very few lived on campus, and many did not own automobiles. They relied instead on community buses to get to campus and then back home again, and they were thus locked into the bus schedule.

Other things were added to the course with the transfer student population in mind. Academic advising briefs were included in lecture announcements to make sure students were aware of critical deadlines and course scheduling events. A "Study Planner" assignment (see Week 1 Workshops in Table A1) was used to ensure that the students made contact with the academic advisors for their intended major, and to get them thinking about pre- and co-requisites as they planned their course map to a degree. Help was provided in navigating campus and in understanding campus tools, resources, and acronyms. These are things that native students already know and that resident freshmen living together learn quickly, but they are new and unfamiliar to the more isolated transfer students until someone takes the time to explain. In the fall 2006 offering of EngE2984, we also recognized and seized the opportunity we had to build community among new transfer students, and that, in itself, made a considerable difference. One of the key things involved in community building was a peer mentoring program for transfer students, the Network for Engineering Transfer Students (NETS), which was established in fall 2005 through funding from an NSF STEP grant (STEP: STEM Talent Expansion Program,

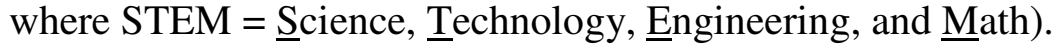

\section{Peer-Mentoring (NETS) and EngE2984}

In the College of Engineering, fall semester peer mentoring programs for engineering freshmen of under-represented populations had shown success in improving retention among participating students. Thus, with the award of an NSF STEP grant in late 2004, fall peer mentoring programs were expanded to serve a greater number of freshman students and new transfer students, GE or not. Details of the expanded peer-mentoring efforts for first-year students have been reported in earlier work, ${ }^{12}$ and the positive impact of peer-mentoring on student retention and success is documented. ${ }^{13-15}$ The Network for Engineering Transfer Students (NETS) was established in fall 2005 as a fall semester only program for new transfer students. As a new program, it had a reasonable number of participating transfer student mentees (21) over the fall 2005 semester. Their participation level seemed to dwindle, though, as the semester continued. In fall 2006, when EngE2984 was first offered, NETS was advertised in advising briefs in EngE2984. NETS participation grew to 41 active mentees, and lasted through the full fall semester. This increase was not by chance. The EngE2984 instructor (Kampe) was also involved with the STEP grant effort, and she facilitated NETS participation by advertising and by scheduling EngE2984 events (e.g., the first test) to coincide with complimentary NETS activities (e.g., an after-test social). About half of the NETS mentees (17 
of the 41) were enrolled in fall 2006 EngE2984, and the level of community established among those transfer students was remarkable. It seemed that the five-credit course alone built a reasonable sense of community among all those enrolled, just by virtue of the amount of shared class time over the semester. The NETS impact, however, added something extra with the social climate cultivated by the upper-class mentors among their mentees. The NETS mentors, of course, were transfer students themselves.

In the summer 2007 offering of EngE2984, the NETS peer mentoring program was fully integrated with the course. First, three of the four mentors for summer 2007 had taken EngE2984 in fall 2006, so they were very familiar with the course as well as being successful transfers to Virginia Tech. Additionally, a good portion of each Friday workshop was used for NETS activities. The mentors planned informative presentations, demonstrations, and oncampus field trips, and each Friday they brought food for all. The atmosphere was very social, but there was organization behind the course/mentoring integration. During the first workshop of summer 2007 EngE2984, the four mentors came in and introduced themselves, offering some information about their majors, their interests, and their experiences as a successful transfer student. The enrolled students were then asked to choose a mentor, and peer mentoring teams were assigned based on their choices. Beyond the Friday workshop interactions, the mentors contacted each person on their team at least once a week. Mentors also scheduled activities outside of class time, such as cookouts and community field trips to local happenings. Each week the mentors were required to submit a report to a mentoring program administrator (not the EngE2984 instructor) on mentoring activity and on any developing issues regarding the mentees. Over the six week summer session, the mentors were paid through STEP grant funds and they were given an allowance for one off-campus team meal. The students enrolled in EngE2984 were required only to participate in the Friday workshop mentoring efforts; any participation beyond that class integration was voluntary.

Though the summer 2007 NETS participation during class time activities was required through integration of the peer mentoring program with the course, many students participated beyond that extent during the summer session. Additionally, many summer EngE2984 students continued NETS participation through the subsequent fall 2007 semester by choice. A summary of active fall NETS participation since its establishment is provided in Table III, along with associated counts for EngE2984 enrollments and for transfer students entering Virginia Tech. Summer II 2007 NETS participation is not included in Table III because that participation was mandatory. The NETS participation for fall semesters listed in Table III was completely voluntary and through self-selection by the students. For fall 2006 and 2007, there is a strong link between the course and the peer mentoring program counts.

\section{Course Evaluation}

Data summarizing evaluation of EngE2984 for both runs are presented in Table IV. Those items preceded by an asterisk are student response items that were extracted from the usual SPOT (Student Perception of Teaching) course evaluations administered on the last day of lecture. The values reported for these items are response averages for the fall 2006 and the summer 2007 runs. The last four items in Table IV reflect actual student success in the course. 
Table III. A summary of fall participation in the NETS peer mentoring program, with associated enrollments in EngE2984 and with entering numbers of transfer students, total and GE.

\begin{tabular}{|l|c|c|c|}
\hline & Fall 2005 & Fall 2006 & Fall 2007 \\
\hline $\begin{array}{l}\text { Number of transfer students entering } \\
\text { Virginia Tech }\end{array}$ & 154 & 127 & 168 \\
\hline $\begin{array}{l}\text { Number of GE transfer students entering } \\
\text { Virginia Tech needing full freshman program }\end{array}$ & 48 & 58 & 38 \\
\hline Number of students enrolled in EngE2984 & NA & 47 & $\begin{array}{c}0 \\
\text { (but 37 in } \\
\text { Summer II 2007) }\end{array}$ \\
\hline Number of active NETS mentees & 21 & 41 & 47 \\
\hline $\begin{array}{l}\text { Number of EngE2984 students among fall } \\
\text { NETS mentees }\end{array}$ & NA & 17 & $\begin{array}{c}\text { 16 (from } \\
\text { Summer II 2007 } \\
\text { enrollment) }\end{array}$ \\
\hline
\end{tabular}

The class averaged grade is the earned GPA for the course on a four point scale with $+/$ - options (e.g., $\mathrm{B}+=3.3 ; \mathrm{B}=3.0 ; \mathrm{B}-=2.7$ ). The number of grades below a $\mathrm{C}$ - reflects those students who finished the course but did not do well enough to move to the next engineering level. Course Withdrawal is an option given to first-year students (freshmen and transfers) at Virginia Tech for six credits. In applying Course Withdrawal, a student can participate in a course through a semester's last full week of classes and then elect to take a "W" grade, which is not used in calculation of semester or cumulative GPA. Course Withdrawal is considered an unsuccessful course attempt. The number of drops indicates the number of students who left the course before the usual drop deadline.

The SPOT values denoted by asterisks and reported in Table IV are essentially the same for both runs of EngE2984 accept for two cases. For gains in "Appreciation of the subject matter and discipline field," the summer group perceived a higher gain, and this is likely due to greater student immersion in the five-credit course when it is taught on an accelerated summer schedule, spending over three hours daily in class for six weeks. The other difference in ratings is for "Textbook adequacy," with the summer group perceiving less usefulness in the course books. There were five texts for this course, and these were five of the six books used in the regular freshman program courses. Additionally, there were several instructor-prepared supplements to read. In the compressed summer version of the course, the reading load could not be spread out to the extent that was possible in the regular fifteen-week fall semester, and it is likely that more summer students failed to find the time or the motivation to learn from textbook readings.

There is also an overall variation in data for the two course runs summarized in Table IV. The SPOT items that ask students to compare EngE2984 to other courses taken at Virginia Tech show a higher frequency of the Not Applicable (NA) response for the summer cohort. This is understandable because many of the summer transfer students were taking only the five-credit 
Table IV. Course evaluation data for both runs of EngE2984.

\begin{tabular}{|c|c|c|}
\hline & Fall 2006 & Summer 2007 \\
\hline Starting enrollment & 47 & 37 \\
\hline \multicolumn{3}{|l|}{$\begin{array}{l}\text { I would rate my gains in this course compared with similar } \\
\text { courses as follows: } \\
\text { (1=less than average; } 2=\text { average; } 3=\text { greater than average; } \\
\text { NA = Not Applicable) }\end{array}$} \\
\hline & $\begin{array}{c}2.3(\mathrm{~N}=35) \\
\mathrm{NA}=0\end{array}$ & $\begin{array}{c}2.3(\mathrm{~N}=30) \\
\mathrm{NA}=1\end{array}$ \\
\hline *b. Logical thinking and problem solving ability. & $\begin{array}{c}2.3(\mathrm{~N}=35) \\
\mathrm{NA}=0\end{array}$ & $\begin{array}{c}2.2(\mathrm{~N}=30) \\
\mathrm{NA}=1\end{array}$ \\
\hline$*^{*}$. Appreciation of the subject matter and discipline field. & $\begin{array}{c}1.9(\mathrm{~N}=35) \\
\mathrm{NA}=0\end{array}$ & $\begin{array}{c}2.4(\mathrm{~N}=30) \\
\mathrm{NA}=1\end{array}$ \\
\hline \multicolumn{3}{|l|}{$\begin{array}{l}\text { How I rate or describe this course compared with others I } \\
\text { have taken at Virginia Tech: } \\
\text { (1=Poor; } 2=\text { Fair; } 3=\text { Good; } 4=\text { Excellent; NA=Not } \\
\text { Applicable) }\end{array}$} \\
\hline & $\begin{array}{c}2.9(\mathrm{~N}=36) \\
\mathrm{NA}=0\end{array}$ & $\begin{array}{c}2.9(\mathrm{~N}=21) \\
\mathrm{NA}=10\end{array}$ \\
\hline *b. Textbook adequacy & $\begin{array}{c}2.8(\mathrm{~N}=36) \\
\mathrm{NA}=0\end{array}$ & $\begin{array}{c}2.5(\mathrm{~N}=21) \\
\mathrm{NA}=10\end{array}$ \\
\hline *c. Teaching, overall & $\begin{array}{c}3.1(\mathrm{~N}=36) \\
\mathrm{NA}=0\end{array}$ & $\begin{array}{c}3.1(\mathrm{~N}=30) \\
\mathrm{NA}=1\end{array}$ \\
\hline \multicolumn{3}{|l|}{$\begin{array}{l}\text { How I rate or describe this course compared with others I } \\
\text { have taken at Virginia Tech: } \\
\text { (1=less than average; } 2=\text { average; } 3=\text { greater than average; } \\
\text { NA = Not Applicable) }\end{array}$} \\
\hline *Effort required & $\begin{array}{c}2.9(\mathrm{~N}=36) \\
\mathrm{NA}=0\end{array}$ & $\begin{array}{c}3.0(\mathrm{~N}=23) \\
\mathrm{NA}=8\end{array}$ \\
\hline *Expected course grade (4 point scale, no +/- options) & $\begin{array}{c}2.8(\mathrm{~N}=35) \\
\mathrm{NA}=0\end{array}$ & $\begin{array}{c}2.9(\mathrm{~N}=31) \\
\mathrm{NA}=0\end{array}$ \\
\hline Class averaged grade (4 point scale, with $+/$ - options) & $2.70(\mathrm{~N}=41)$ & $2.89(\mathrm{~N}=31)$ \\
\hline Number of grades below C- & 2 & 0 \\
\hline Number of Course Withdrawals & 4 & 6 \\
\hline Number of Drops & 2 & 0 \\
\hline
\end{tabular}

* Student Perception of Teaching (SPOT) response items: Values reported for fall 2006 and summer 2007 are student response averages. 
EngE2984 course and it was their first enrollment at Virginia Tech; they thus had no basis for comparison and no way to answer the survey item. For the fall 2006 run, all the enrolled students were full-time, so they carried at least seven other credits in their first enrollment at Virginia Tech and could compare EngE2984 to the other VT courses they were taking. Other than this NA distinction, the SPOT data for both runs have similar response rates and the values reported for both runs are comparable to those observed for other freshman program courses that include computer programming.

The success measure of EngE2984 ultimately lies in how many students were able to move into their respective departments. This measure is also linked to completion of other freshman requirements, some of which were precluded for same semester enrollment due to an EngE pre-requisite for those courses or due to semester credit caps on enrollment. Even so, it is rewarding to note that 27 of the 39 students (or 69\%) who passed EngE2984 in fall 2006 were able to move to College of Engineering departments in spring 2007. For the summer 2007 cohort, 7 of the 31 (or 23\%) passing were moved to CoE departments in the fall 2007 semester. The lower summer percentage indicates that the summer session did not allow the opportunity for transfers to pick up the other freshman requirements they lacked. This is probably due both to the limited number of courses offered in summer sessions and to the lower credit cap on summer enrollments. An additional 11 students from the summer 2007 cohort moved to their departments in early spring 2008, bringing the percentage moved up to 58\%. Something to note in this regard is that the EngE courses are pre-requisites for subsequent engineering courses in $\mathrm{CoE}$ degree paths, and most CoE departments will allow GE students to take their engineering courses as long as those pre-requisites are met. For GE transfers, this means they can continue to make progress toward their engineering degree once the freshman program courses are covered.

The number of students who were not successful in EngE2984 (Course Withdrawals, drops, and grades below C- in Table IV) was 8 of 47 in fall 2006 and 6 of 37 in summer 2007, or roughly $17 \%$ in each case. It was determined that the computer programming benchmark alone was the deciding factor for just one unsuccessful case in fall 2006 but for three cases in summer 2007. The higher incidence of a programming roadblock in the summer session likely stems from the compressed aspect of the summer course, which may not have provided sufficient time for some students to process new concepts and keep pace with the accelerated course schedule. This explanation is also reflected in comments from the summer mentors (see the Appendix), and it was echoed in free response comments on the SPOT course evaluations.

\section{Student Evaluations of the NETS Mentors/Mentoring}

Student evaluation of the mentors and the NETS mentoring program for fall 2006 and summer 2007 are presented in Tables V, VI, and VII. In fall 2006, NETS mentees included GE transfer students who were enrolled in EngE2984 (17), GE transfers who were in the regular freshman program courses, and transfer students who were admitted directly to their respective CoE departments. The fall 2006 survey respondents are thus an unknown mix of these components. For summer 2007, NETS mentees comprised only GE transfer students who were enrolled in EngE2984. Both cohort data sets for all three tables were collected by electronic survey with e-mail invitations and reminders to participate. There is a substantial difference in the survey response rates for the two NETS cohorts, with the summer rate more than twice that 


\begin{tabular}{|c|c|c|c|c|c|c|c|c|c|c|c|c|c|c|c|c|}
\hline 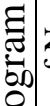 & & 㕅 & 0 & $\varrho$ & $\varrho$ & 인 & in & 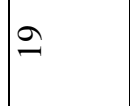 & $\underset{\aleph}{\infty}$ & \pm & $\stackrel{\Delta}{\Delta}$ & సे & in & 0 & in & 0 \\
\hline & 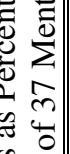 & 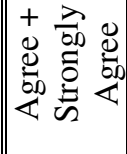 & 8 & \& & § & ৪ & $\infty \infty$ & 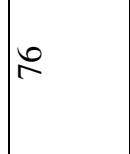 & $\stackrel{\infty}{+}$ & $\infty$ & రु & $\bar{F}$ & $\curvearrowleft$ & $\infty$ & \&̊ & 8 \\
\hline & 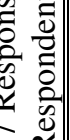 & 氶 & 0 & 0 & 0 & 0 & $n$ & in & \pm & 0 & 0 & 0 & 0 & 0 & 0 & 0 \\
\hline & 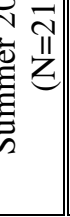 & 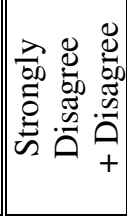 & 0 & 0 & 0 & 0 & 10 & 0 & 0 & 0 & $n$ & 0 & 0 & in & in & 0 \\
\hline 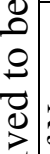 & & $\| \widetilde{z}$ & 0 & 0 & 0 & 0 & 10 & 0 & సি & 0 & 잉 & 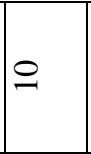 & 10 & 10 & 10 & 0 \\
\hline & . & 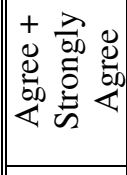 & 8 & 8 & ৪ & ৪ & 8 & ৪ & $\stackrel{2}{2}$ & $?$ & $\infty$ & $\infty$ & /2 & ৪ & ৪ & ৪ \\
\hline & 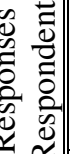 & 泀 & 0 & 0 & 0 & 0 & 10 & 0 & 0 & 0 & 0 & $\varrho$ & $\varrho$ & 10 & 0 & $\varrho$ \\
\hline & 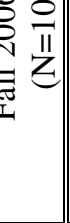 & 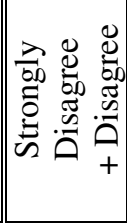 & 10 & 0 & 0 & 0 & 10 & 10 & 잉 & ○ & 은 & 0 & 0 & $\varrho$ & $\varrho$ & 0 \\
\hline & 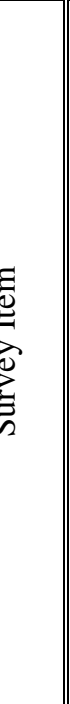 & & 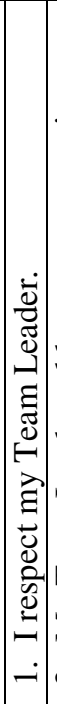 & 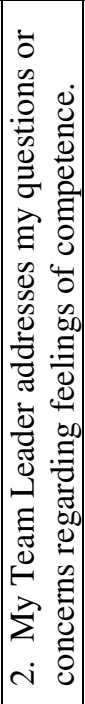 & 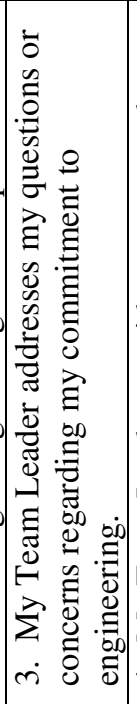 & 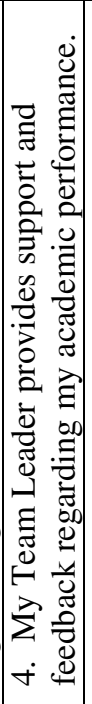 & 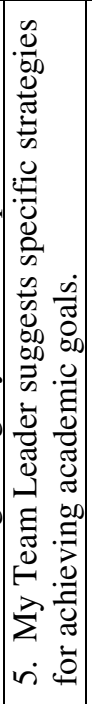 & 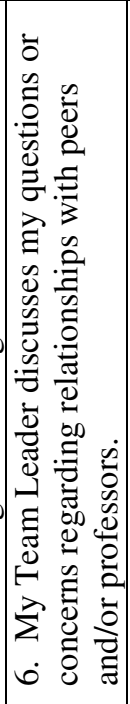 & 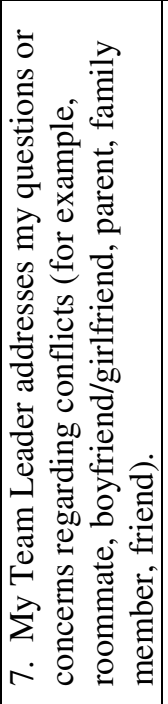 & 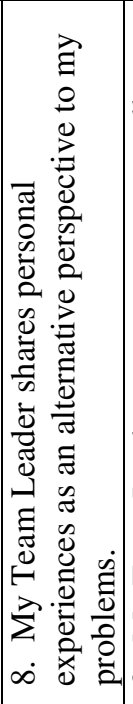 & 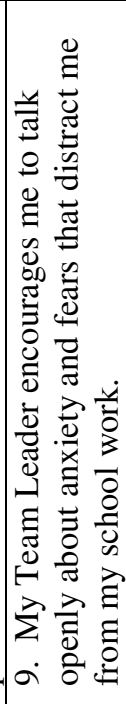 & 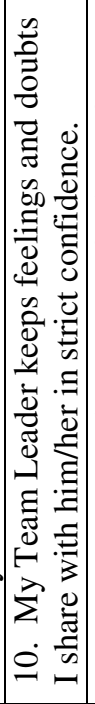 & 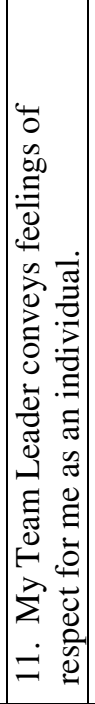 & 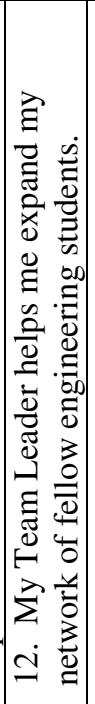 & 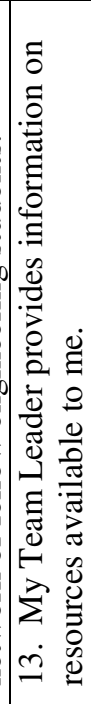 & 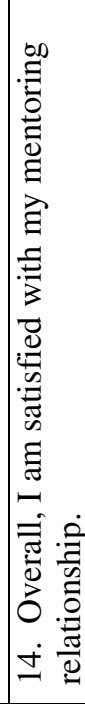 \\
\hline
\end{tabular}


Table VI. Survey responses on perceived mentor attributes.

\begin{tabular}{|l|c|c|}
\hline Please check all that you would use to describe your team Leader: \\
\hline Descriptor & $\begin{array}{c}\text { Fall 2006 Responses as } \\
\text { Percentage of N } \\
\text { (N=10 Respondents of } \\
41 \text { Mentees })\end{array}$ & $\begin{array}{c}\text { Summer 2007 Responses as } \\
\text { Percentage of N } \\
\text { (N 21 Respondents of } \\
37 \text { Mentees })\end{array}$ \\
\hline Effective conversationalist & 80 & 76 \\
\hline $\begin{array}{l}\text { Distracted/anxious to finish } \\
\text { meeting }\end{array}$ & 0 & 5 \\
\hline Approachable & 70 & 100 \\
\hline Intimidating & 0 & 0 \\
\hline Supportive of others & 60 & 86 \\
\hline Attentive to what I am saying & 60 & 95 \\
\hline $\begin{array}{l}\text { Shows favoritism to team } \\
\text { members }\end{array}$ & 0 & 5 \\
\hline Confident & 70 & 90 \\
\hline Helpful & 80 & 90 \\
\hline Passive & 10 & 5 \\
\hline Interested in what I am saying & 70 & 81 \\
\hline Likeable & 70 & 95 \\
\hline Cold and distant & 0 & 0 \\
\hline Argumentative & 0 & 0 \\
\hline Flexible & 70 & 57 \\
\hline A good listener & 60 & 76 \\
\hline Relaxed and easy to be around & 90 & 86 \\
\hline Interrupts too much & 0 & 0 \\
\hline
\end{tabular}

for fall 2006. This difference is likely due to the strong association of the mentoring program with the EngE2984 course for summer 2007.

Data on how students perceived their needs to be met by their mentor and the mentoring program are provided in Table $\mathrm{V}$ as percentages of the total number of respondents. For these items, responses were selected from a five-choice Likert scale (Strongly Disagree, Disagree, Neutral, Agree, Strongly Agree) with a Not Applicable (NA) option. Reported responses are grouped by adding the Strongly Disagree to Disagree responses and by adding the Agree to Strongly Agree responses. Neutral and NA responses are reported separately. From Table V, it appears that respondents are generally satisfied with how NETS met the needs anticipated by the survey authors. With respect to the percentages reported, students sometimes did not respond to an item and these omitted responses account for sums less than $100 \%$. Also, since the results are reported only to the nearest percentage point, rounding causes some sums to total to $101 \%$ (see Item 9 for summer 2007: $5+10+62+24=101)$.

An assessment of perceived attributes of the NETS mentors is provided in Table VI. Respondents were asked to check all items that apply, and results are listed as percentages of the 
Table VII. Free response comments on mentors/mentoring survey.

\begin{tabular}{|l|l|}
\hline Fall 2006 & Summer 2007 \\
\hline $\begin{array}{l}\text { [Name omitted] is an excellent man. He } \\
\text { helped me many times. I felt if I needed } \\
\text { anything I could call him and if he did not } \\
\text { answer he always responded quickly. The } \\
\text { only complaint I have with the program, not } \\
\text { with [name omitted] was that he was in the } \\
\text { same classes (academic level) as I and we } \\
\text { could not really discuss advanced classes. I } \\
\text { feel if you had a higher academic level } \\
\text { student mentoring it would be more } \\
\text { beneficial. }\end{array}$ & $\begin{array}{l}\text { I thought [name omitted] was a very good } \\
\text { mentor, however I felt that the mentor } \\
\text { program was poorly designed. I suppose } \\
\text { mentor groups and the lack of information of } \\
\text { events if they were there. }\end{array}$ \\
\hline $\begin{array}{l}\text { Very friendly and made me feel extremely } \\
\text { comfortable right from the start }\end{array}$ & $\begin{array}{l}\text { While I was only around [name omitted] } \\
\text { during the class-time activities, I got a } \\
\text { positive impression of him generally. } \\
\text { Considering my limited exposure to him, I } \\
\text { think he makes a good mentor. }\end{array}$ \\
\hline $\begin{array}{l}\text { Glad I got to meet him! } \\
\text { very helpful. }\end{array}$ & \\
\hline He also knows where good food is. & \\
\hline
\end{tabular}

total number of respondents. The results indicate that mentors made a favorable impression on the respondent mentees, with only two respondents in summer 2007 checking negative characteristics (5\% for "Distracted..." and 5\% for "Shows favoritism...").

Students were given the opportunity to enter free response comments on mentors and the mentoring program. There were only a few of these, and they are listed in Table VII. Of particular note is the first listing for fall 2006 that expresses a desire for a mentor with "higher academic level," which would allow discussion of more advanced classes. This is a good point, but it is difficult to address. Transfer students often enter Virginia Tech with junior status, leaving only seniors as mentors with higher academic levels. Restricting NETS mentoring positions to seniors has not been possible in past falls due to the difficulty in attracting upperclass students to mentoring positions, even paid positions. For NETS mentors, we feel it is imperative that the mentor be a successful transfer student, and that eliminates the large native portion of the upper-class pool. We expect, however, that the growing numbers of NETS mentees will increase the size of our future pool of possible NETS mentors.

\section{Insights from the Summer 2007 NETS Mentors}

At the conclusion of the Summer II 2007 session, we asked the NETS mentors to submit their thoughts on the EngE2984/peer mentoring integrated effort. The mentor comments are summarized below, and the full submissions are provided in the Appendix. 
In terms of academics, the mentors felt that the course was a heavy load for a summer session and that there was not sufficient time to process new concepts. It was suggested that the NETS program could be improved by offering academic support as well as social networking. Additionally, one mentor thought expanding the EngE2984 course to a two-session course in the summer would better serve the transfer students. In answer to these comments, we acknowledge that a five-credit course on an accelerated summer schedule is a heavy load, for both students and instructor. Though this should be expected since a five-credit course is nearly twice the load of the more common three-credit courses, many students seemed surprised at the amount of work involved. In course evaluations (Table IV) for "Effort required," responses for both runs indicate a greater than average rating almost unanimously. Academic support through NETS may be something to look into for future runs, but it would be far beyond expected duties for the mentors to serve as tutors due to the varying academic levels of the mentees and the varied engineering majors that mentees are pursuing. Perhaps facilitating help sessions for the EngE2984 course would be a feasible way to go. Expanding the EngE2984 course to two summer sessions would not be helpful to transfers because the first summer session starts too early for them, beginning in the last third of May when some community colleges are still in session. If a two-session course were a viable option for the transfer students, most of them would have been taking the regular freshman program courses that are offered consecutively over the two summer sessions at Virginia Tech. Perhaps expansion of the EngE2984 session by one or two weeks would be something to consider that would provide one day off each week, or a mini-break at mid session.

Regarding the social component provided by NETS, the mentors felt that it was beneficial for the transfer students, but perhaps more so for younger transfers. There was a suggestion for more organized socials to increase mentee participation, and a comment that the course integration made mentoring much easier due to guaranteed time with the mentees. Mentoring team size was also mentioned, and it was acknowledged that reducing team size would facilitate organizing team outings and events but that there would be a trade-off with reduced networking opportunities.

\section{Conclusions: Course Impact on Transfer Students - An Instructor's/Advisor's Perspective}

The main reason for offering a single course to replace the freshman program for transfer students is to move GE transfer students to their degree-granting departments as soon as possible - ideally after their first semester of enrollment at Virginia Tech. This does at least two things. First, the time to graduation will be shortened by at least one semester with a fall offering of EngE2984, and quite possibly by a full year with a summer offering. This is important in recruiting transfer students, but it also means that the transfer students will connect with their degree-granting departments earlier, which should improve retention. Secondly, physically bringing the transfer students together through EngE2984 course enrollment offers the opportunity to build community among them, and that peer support will also have a positive impact on retention. The integration of peer mentoring with the course has a strong potential to further this community-building effort and to improve the climate of the receiving campus for transfer students. After teaching EngE2984 twice, with the transfer students' situations in mind, it was gratifying to note that many of the things we thought would benefit transfer students were 
also highlighted by another author as tips to teaching in a diverse community college classroom. $^{11}$

\section{Acknowledgements}

The authors are grateful for funding from the Virginia Tech Provost Office to support the summer offering of EngE2984. We also thank the Department of Engineering Education for providing the Friday workshop food. The NETS peer mentoring is supported by funds from the National Science Foundation (NSF), and we gratefully acknowledge that support.

This material is based upon work supported by the National Science Foundation under Grant Number DUE-0431646. Any opinions, findings, and conclusions or recommendations expressed in this material are those of the authors and do not necessarily reflect the views of the National Science Foundation.

\section{Bibliography}

1. American Society for Engineering Education. "College costs rise faster than inflation, student aid." First Bell, October 23, 2007.

2. Cohen, Jodi S. and Mary Owen. "College costs rise faster than inflation." chicagotribune.com, 10:38 PM CDT, October 22, 2007, accessed October 23, 2007.

3. Glater, Jonathan D. "College Costs Rising at Double the Inflation Rate." The New York Times, nytimes.com, October 22, 2007, accessed October 23, 2007.

4. "Federal Student Aid to Undergraduates Shows Slow Growth, While Published Tuition Prices Continue to Increase." at www.college board.com/press/releases/189547.html accessed October 23, 2007.

5. National Academy of Engineering and National Research Council. Enhancing the Community College Pathway to Engineering Careers, Mattis, Mary C. and John Sislin, eds. Washington, DC: The National Academies Press, 2005.

6. Finken, Dee Anne. “Alternate Roads to Engineering.” SWE Magazine, Society of Women Engineers, Fall 2006, pp. 28-36.

7. Associated Press. "Virginia colleges brace for increase of new students." The Roanoke Times, 20 July 2005, Virginia Section p.4 cols.5-6.

8. Selingo, Jeffrey. “ Role Reversal.” ASEE Prism, American Society for Engineering Education, March 2007, pp. 26-31.

9. Grites, Tom. "Advising Transfer Students." National ACademic ADvising Association (NACADA) at www.nacada.ksu.edy/AAT/NW27_3.htm\#16 accessed December 17, 2007.

10. Jaschik, Scott. "Closed Doors." Inside Higher Ed, insidehighered.com, June 19, 2006, accessed December 17, 2007.

11. Fogg, Piper. "A Dozen Teaching Tips for Diverse Classrooms." The Chronicle of Higher Education Community Colleges, from the issue dated October 26, 2007, by e-mail subscription.

12. Edmister, Whitney, et al. "Lessons Learned: Implementing a Large-Scale Peer Mentoring Program." Proceedings of the 2006 ASEE Annual Conference \& Exposition, Session 2653, June 2006, Chicago, IL.

13. Loftus, Margaret. "Lending a Hand.” ASEE Prism, American Society for Engineering Education, January 2005, pp. 24-29.

14. Wadsworth, Emily M. Giving Much / Gaining More. West Lafayette, Indiana: Purdue University Press, 2002.

15. Ender, Steven C. and Fred B. Newton. Students Helping Students. San Francisco: Jossey-Bass Publishers, 2000. 


\section{Appendix}

Table A1. Course content and delivery breakdown for summer 2007 offering of EngE2984, the course for transfers.

\begin{tabular}{|c|c|c|c|}
\hline Week & Dates & Lectures & Workshops \\
\hline 1 & $\begin{array}{l}\text { Monday, July } 2 \\
\text { Tuesday, July } 3\end{array}$ & $\begin{array}{l}\text { 1. Course Introduction } \\
\text { Design } \\
\text { 2. Design, Sketching, } \\
\text { Problem Solving }\end{array}$ & $\begin{array}{l}\text { 1. Design - Product Comparison } \\
\text { 2. Assign Teams and } \\
\text { Major Design Project } \\
\text { Study Planners Assigned }\end{array}$ \\
\hline \multicolumn{4}{|c|}{ Wednesday, July 4, 2007 - NO CLASSES - Lecture 3 and Workshop 3 cancelled } \\
\hline & $\begin{array}{l}\text { Thursday, July } 5 \\
\text { Friday, July } 6\end{array}$ & $\begin{array}{l}\text { 4. Multiview Projection Theory } \\
\text { 5. Pictorials }\end{array}$ & $\begin{array}{l}\text { 4. Design - Reverse Engineering } \\
\text { 5. Problem Solving } \\
\text { Sketching }\end{array}$ \\
\hline 2 & $\begin{array}{l}\text { Monday, July } 9 \\
\text { Tuesday, July } 10 \\
\text { Wed., July } 11 \\
\text { Thurs., July } 12 \\
\text { Friday, July } 13\end{array}$ & $\begin{array}{l}\text { 6. Teamwork \& Project Management } \\
\text { 7. Dimensioning } \\
\text { 8. Special Views } \\
\text { 9. Working Drawings, Design } \\
\text { 10. Problem Solving }\end{array}$ & $\begin{array}{l}\text { 6. Ethics assigned and Pictorials } \\
\text { 7. Ethics work \& Study Planners } \\
\text { 8. Dimensioning \& Section Veiws } \\
\text { 9. Print Reading } \\
\text { 10. Problem Solving, Graphing }\end{array}$ \\
\hline 3 & $\begin{array}{l}\text { Monday, July } 16 \\
\text { Tuesday, July } 17 \\
\text { Wed., July } 18 \\
\text { Thurs., July } 19 \\
\text { Friday, July } 20\end{array}$ & $\begin{array}{l}\text { 11. Graphing } \\
\text { 12. TEST } 1 \text { in class } \\
\text { 13. Go over Test } 1 \text {, Algorithm } \\
\text { Development, Boolean Algebra, Binary } \\
\text { Numbers } \\
\text { 14. Flowcharting } \\
\text { 15. MATLAB Functions }\end{array}$ & $\begin{array}{l}\text { 11. Graphing \& Empirical Functions } \\
\text { 12. Graphing with Error Bars } \\
\text { 13. MATLAB Graphing } \\
\text { 14. Flowcharting } \\
\text { 15. MATLAB }\end{array}$ \\
\hline 4 & $\begin{array}{l}\text { Monday, July } 23 \\
\text { Tuesday, July } 24 \\
\text { Wed., July } 25 \\
\text { Thurs., July } 26 \\
\text { Friday, July } 27\end{array}$ & $\begin{array}{l}\text { 16. Script Files } \\
\text { 17. Selection/Branching } \\
\text { 18. Repetition/Loops } \\
\text { 19. Repetition/Loops } \\
\text { 20. Repetion and Selection }\end{array}$ & $\begin{array}{l}\text { 16. MATLAB } \\
\text { 17. MATLAB } \\
\text { 18. MATLAB } \\
\text { 19. MATLAB } \\
\text { 20. MATLAB }\end{array}$ \\
\hline 5 & $\begin{array}{l}\text { Monday, July } 30 \\
\text { Tuesday, July } 31 \\
\text { Wed., August } 1 \\
\text { Thurs., August } 2 \\
\text { Friday, August } 3\end{array}$ & $\begin{array}{l}\text { 21. Review } \\
\text { 22. TEST } 2 \text { in class } \\
\text { 23. Go over Test 2, Communication, } \\
\text { Design Reports } \\
\text { 24. MATLAB Programming Review } \\
\text { 25. Analog and Digital Signals }\end{array}$ & $\begin{array}{l}\text { 21. MATLAB } \\
\text { 22. MATLAB Simultaneous } \\
\text { Equations } \\
\text { 23. Ethics Film } \\
\text { 24. Analog and Digital Signals } \\
\text { 25. Encoding and Transmitting Data }\end{array}$ \\
\hline 6 & $\begin{array}{l}\text { Monday,August } 6 \\
\text { Tuesday,August } 7 \\
\text { Wed., August } 8 \\
\text { Thurs., August } 9\end{array}$ & $\begin{array}{l}\text { 26. Communication, Presentations } \\
\text { 27. Networking } \\
\text { 28. Design } \\
\text { 29. Review } \\
\text { Teaching Evaluations }\end{array}$ & $\begin{array}{l}\text { 26. Encoding and Transmitting Data } \\
\text { 27. Networking } \\
\text { 28. Design Presentations } \\
\text { 29. Design Presentations } \\
\text { Teaching Evaluations }\end{array}$ \\
\hline & s & קOT & :00 AM Randolph 221 \\
\hline
\end{tabular}


Table A2. Major design project assignment.

\section{Major Design Project \\ EngE 2984 Summer II 2007}

General Task Description:

Your design team must select an electro-mechanical device to disassemble and to design a modification for. As a group, you are to reverse engineer the device, fully describing its operation with a complete set of working engineering drawings that you produce using Inventor (including detail drawings of all parts and an assembly drawing of the device). Following that, you must design a non-trivial original modification for the device and create the Inventor objects (and their detail drawings) to implement that modification in the assembly drawing of the device. Please note that actual implementation of the modification is not required and the simple elimination of a design feature will not be an acceptable modification.

Some General Rules:

1. You must select a device as a team.

2. Your device selection must receive written instructor approval. You may seek approval beginning Friday, July 7, 2007.

3. Safety must be your top priority at all disassembly sessions.

4. You must disable/cut all connectors for power outlets BEFORE any disassembly of your device.

5. You must wear eye protection during all disassembly sessions; Chemistry goggles are available at the bookstores.

6. You may not disassemble a device or device part beyond manufacturer warnings; please check with instructor for the level of disassembly required for your device.

7. Your device modification plan must receive written instructor approval.

8. No duplicate team efforts will be allowed; i.e., your team must work with a device unique to the class as a whole (both CRNs).

9. You must keep all parts of the device until the course concludes.

10. You should not require more than $\$ 5.00$ per team member to purchase a device or any disassembly tools, and you should have instructor approval of the device before any purchases are made.

Some Device Possibilities:

Electric pencil sharpener

Coffee maker

Electric can opener

Sewing machine

Electric stapler

Kitchen blender

Power screwdriver Hair dryer

Other Important Notes:

The device that you actually take apart does not need to be new, or even in working condition. As long as the mechanism of operation can be determined and Inventor drawings can be made for all parts, the device itself can be used/broken. As a source for inexpensive electro-mechanical devices, please consider the local thrift shops: YMCA on North Main Street, Blacksburg; Humane Society on Ellett Road, Blacksburg; Salvation Army on Roanoke Street, Christiansburg; Goodwill on Peppers Ferry Road, Christiansburg. Your family may also be able to offer a device that is no longer needed. 


\section{Summer 2007 NETS Mentor Comments:}

\section{Mentor \#1:}

The NETS program seems like a good idea in the Summer Session form - however NETS currently appears to be only a social group. Any academic assistance to the mentees was incidental and certainly not planned. The older students didn't really seem to need the social aspect of NETS though it did help some of the younger transfers. I was asked a grand total of one question by a team member the entire session. The Friday workshops seemed as if they were planned more for relaxation and entertainment than real learning. It is my belief that if NETS were to implement some systems for academic support instead of just social interaction, it would be a program superior to the one we have now. Considering the number of people who dropped the class during the session, this seems rather important.

The current program also feels a little bit too aimless. The main issue is getting feedback from the mentees. Our attempts at contacting our mentees were often met with a blind eye. The feedback from the mentees would help us figure out what information they might want us to convey to them - a feat especially difficult considering how rarely we received responses. Considering we only saw most of our mentees around five to six times, perhaps a larger mixer or social at the beginning of the NETS term would be in order. The mentees would get a better chance to interact with us as well as to meet the other students with whom they likely have classes.

To boil down the ways I think NETS can be improved:

Increased academic support

Increased mentee response (hopefully a social or mixer would help)

\section{Mentor \#2:}

By taking the 5 credit class and putting it into 6 weeks, I think it was a little bit too much for some students to handle. If you get behind, there really is no time to catch up because you'll already have another assignment due. You don't have the time to build the foundation before you are required to use that knowledge and apply it. However, I still think the class is a good idea because it allows students to take their in-major classes in the fall, which is particularly useful for the students transferring in a lot of credits.

My favorite thing about this class is that it puts all the NETS students together. It made it a lot easier as a mentor to not have to assemble my entire team. With the other mentoring programs, all the freshmen live on campus and are in one of the ENGE 1024 sections. With NETS, since every transfer is different, you don't have that common link. The 5 credit transfer class serves as a way to unite the NETS students and allows the NETS mentors to have more contact. It helps build the relationships of the program.

Overall, I think NETS and the other mentoring programs help students. Virginia Tech is such a large school with so many opportunities and programs that people really need resources like NETS. The mentors are not only resources to the university but we also build relationships. It is those relationships that make the university seem smaller and "hide" the fact you are only 1 of 25,000 students. 
Mentor \#3:

I enjoyed being a part of this program because I met a lot of people in the same position I was in who have the same questions and issues that I had. I still like to mention the fact that all the people I take classes with and hang out with today I met through NETS. Even if the students don't connect with their own mentor, with the number of people on the team they will usually find someone else to connect with. If they don't know anyone here, as it was in my case, there couldn't be anything better than NETS. For the Mentors I agree with the other Mentors that smaller group sizes will make organizing team events and meetings easier, but will in turn reduce the number of other transfer students for the team members to meet. So there would definitely be a trade off in making smaller group sizes, which really only benefit the Mentor in my opinion. The idea of incorporating this program with the class was brilliant. The team members see each other daily, in the summer, and during the year it would still be 3 times a week. That is the reason most of my group, as a mentee, clicked because 7 of us had the same class MWF at 9 in the morning. We eventually started doing homework together, studying together and now just hanging out together. This is of course not a perfect world and not all the outcomes will be this way, but if students were placed in groups according to the classes they were taking I think 90 percent of the teams would end up this way. This is a hard task to accomplish since all the transfers are in need of different courses to get on track, but if there was someway to assign teams by common classes I feel the outcomes would be better.

I just want to thank you all, Dr. Kampe, Whitney and Christi for allowing me to be a mentor this summer and I will see you all in the future!

\section{Mentor \#4:}

I think that the EngE 2984 summer class was a great success. It was something that greatly expedited the process of getting nestled into the Virginia Tech engineering community for transfer students. The mentor program helped very much also in that it allowed the students to speak with four different transfer students just like them that had been though a similar experience.

Many of the students this summer were hit hard with the amount of work they had to do for this class. It was an intense experience for all of them. Some of the students did not have as much trouble learning the material; the students who did have to spend time learning concepts for the first time probably experienced a great deal more trouble.

I think that to improve the summer session, students should have to fill out a form before the session starts that asks them how well they know different topics that will be discussed in class over the next few weeks. If a student informs that he or she has never seen a certain topic before, perhaps the teacher of the class can offer a study session after the class on the same day that will allow anyone who is uncomfortable with the material to ask more questions about it. I also suggest that the class be spread over more time. A two summer session 2984 would probably be more beneficial for students academically. I'm not sure what the goals of the class are, but if they are to teach the students new concepts, I don't believe six weeks is enough for this class. 